\title{
Observations on the metabolism of alcohol in man
}

\author{
By E. W. BARNES, N. J. COOKE, A. J. KING AND R. PASSMORE \\ Department of Physiology, University of Edinburgh
}

(Received 8 February $1965-$ Accepted 14 fune 1965)

Orthodox views are that alcohol has no specific dynamic action and that the rate of alcohol metabolism is not increased by muscular exercise. Both of these views have recently been challenged. Perman ( 1962 ) claims to have demonstrated an increased rate of oxygen utilization by man after ingestion of alcohol. Nagamine, Tezuka, Yamakawa \& Suzuki (196I) produce evidence that the blood alcohol level falls faster in a subject who is exercising than in one at rest. In this paper we describe experiments in which we have failed to confirm the results of these authors and our observations substantiate the classical view. The experiments also show that at rest the ingestion of alcohol spares the utilization of fat but has no significant effect on the rate of carbohydrate and protein metabolism. We also record some observations on the water balance after the ingestion of alcohol.

\section{EXPERIMENTAL}

Subjects. The experiments were conducted on nine male subjects. Table I gives some relevant physical characteristics.

Experimental regime. Each subject was studied on three separate occasions. These regimes may be designated as Rest, Rest with alcohol, and Exercise with alcohol. The order of the three regimes was randomized for all subjects.

Table 1. Some physical characteristics of the subjects

(Mean values and standard deviations)

$\begin{array}{llll}\text { Number } & 9 & \text { Height }(\mathrm{cm}) & 178 \pm 14 \\ \text { Age (years) } & 20-2 \mathrm{r} & \text { Surface area }\left(\mathrm{m}^{2}\right) & 1 \cdot 85 \pm 0 \cdot 14 \\ \text { Weight }(\mathrm{kg}) & 69^{\prime} 4 \pm 4 \cdot 3 & \text { Theoretical basal metabolism }(\mathrm{ml} \mathrm{O} / \mathrm{min}) & 248 \pm \mathrm{I} 8\end{array}$

On each occasion the subject reported to the laboratory after a $16 \mathrm{~h}$ fast. He rested, sitting quietly, usually reading, for $30 \mathrm{~min}$, when his metabolism was measured by indirect calorimetry. He was then weighed and subsequently observed for $6 \mathrm{~h}$. In the series designated as Rest, the subject sat in an easy chair during the whole period. He was given nothing to eat but received a water allowance of $100 \mathrm{ml} / 65 \mathrm{~kg}$ bodyweight repeated every hour. During each hour of the period of observation, his metabolism was determined on two occasions.

In the series Rest with alcohol, the experimental regime was identical to the above except that at the beginning of the $6 \mathrm{~h}$ period the subject was given $100 \mathrm{ml}$ whisky $/ 65 \mathrm{~kg}$ body-weight with the same hourly water allowance as given in the previous regime. 
This dose of alcohol $\left(3{ }^{1} \cdot 5 \mathrm{~g} / 65 \mathrm{~kg}\right)$ caused a little euphoria in all the subjects and some unsteadiness of the gait for an hour or so, but this was not sufficient to interfere with the course of the experiment.

For the series designated Exercise with alcohol, the regime was the same as for Rest with alcohol, except that the subject walked on a treadmill for the first $20 \mathrm{~min}$ of each hour at a speed of 4 mile/h on a gradient of $I$ in 20, during which period the respiratory exchanges were measured. The total duration of exercise was thus $2 \mathrm{~h}$ and the distance walked 8 miles. A single measurement for the resting metabolism was made each hour about to min after the exercise. The hourly water allowance was doubled to $200 \mathrm{ml} / 65 \mathrm{~kg}$ during this regime.

Blood was withdrawn at the end of each hour for estimation of the alcohol content.

In all experiments the subjects were tested for postural stability every hour. The test lasted $5^{-10} \mathrm{~min}$ and the results will be reported elsewhere.

Indirect calorimetry. Expired air was collected in a Douglas bag for all experiments at rest. For the exercise experiments a Max-Planck Respirometer was used. Gas analysis was performed with the Lloyd-Haldane apparatus.

Blood alcohol. Immediately after withdrawal the blood was deproteinized and the protein-free extract was stored in a deep-freeze. The alcohol content of each extract was subsequently determined by an enzymic method.

Urine. Urine was collected and measured over the $6 \mathrm{~h}$ period, and the nitrogen content determined by Kjeldahl's method.

\section{RESULTS}

Table 2 shows the mean of all the values for oxygen consumption and the RQ at rest with and without alcohol. It also shows the relative values for the oxygen consumption at half-hourly intervals over the first $3 \mathrm{~h}$. Only mean values are given in the table: after alcohol the metabolic rate of each subject showed no more than the

Table 2. The oxygen consumption and respiratory quotient of the subjects at rest with and without alcohol

\begin{tabular}{|c|}
\hline $\begin{array}{l}\mathrm{O}_{2} \text { uptake* }(\mathrm{ml} / \mathrm{min}) \\
\mathrm{RQ}^{*} \\
\left.\mathrm{O}_{2} \text { uptakef (initial value }=100\right) \\
\text { After } 15 \mathrm{~min} \\
\text { After } 45 \mathrm{~min} \\
\text { After } \mathrm{I} \text { h } 15 \mathrm{~min} \\
\text { After } \mathrm{h} \text { h } 45 \mathrm{~min} \\
\text { After } 2 \mathrm{~h} \text { I } 5 \mathrm{~min} \\
\text { After } 2 \mathrm{~h} 45 \mathrm{~min}\end{array}$ \\
\hline
\end{tabular}

$\begin{array}{cc}\text { Rest } & \text { Rest with alcohol } \\ \mathbf{2 8 3} \pm \mathbf{2 8} & \mathbf{2 8 8} \pm \mathbf{3 4} \\ 0.787 \pm 0.067 & 0.782 \pm 0.055 \\ & \\ \text { 100 } & \text { 101 } \\ 98 & 100 \\ 99 & 95 \\ 99 & 97 \\ \text { 101 } & 99 \\ \text { 101 } & 99\end{array}$

* Mean values and standard deviations of twelve measurements on each subject over a $6 \mathrm{~h}$ period.

$\dagger$ Mean values of single measurements on each subject.

normal variations found in the postabsorptive state and there is no evidence of a specific dynamic effect. 'The mean values are $14 \%$ and $16 \%$ above the mean theoretical basal metabolic rate of the subjects (Table I). This could be attributed to the fact that the subjects were sitting reading during the observations. 
Table 3 shows the mean blood alcohol levels at hourly intervals after ingestion and Table 4 the calculated rates at which the alcohol was cleared from the blood. There is no evidence that the alcohol was cleared any faster during exercise. All the figures lie within normal limits.

Table 3. Blood alcohol levels $(\mathrm{mg} / \mathrm{100} \mathrm{ml})$ after a dose of alcohol $\left(3{ }^{1} 5 \mathrm{~g} / 65 \mathrm{~kg}\right)$ in subjects at rest and exercising

(Mean values and standard deviations for nine subjects)

Time after ingestion

(h)

I
2
3
4
5
6
Rest with alcohol

$$
\begin{array}{r}
61 \pm 7 \cdot 4 \\
50 \pm 5 \cdot 5 \\
40 \pm 8 \cdot 4 \\
26 \pm 9 \cdot 2 \\
17 \pm 9 \cdot 2 \\
9 \pm 8 \cdot 4
\end{array}
$$

Exercise with alcohol

$$
\begin{array}{r}
58 \pm 5 \cdot 5 \\
52 \pm 5 \cdot 7 \\
38 \pm 5 \cdot 4 \\
26 \pm 5 \cdot 2 \\
17 \pm 9 \cdot 3 \\
8 \pm 6.9
\end{array}
$$

Table 4. The rate of clearance of alcohol from the blood ( $\mathrm{mg} / \mathrm{kg}$ body-weight $h$ ) in each subject at rest and with exercise

$\begin{array}{cccccc}\text { Subject no. } & \text { At rest } & \text { With exercise } & \text { Subject no. } & \text { At rest } & \text { With exercise } \\ \text { I } & 68 & 76 & 6 & 84 & 91 \\ 2 & 70 & 71 & 7 & 84 & 92 \\ 3 & 81 & 68 & 8 & 77 & 70 \\ 4 & 85 & 83 & 9 & 72 & 71 \\ 5 & 55 & 60 & \text { Mean } & 75 & 76\end{array}$

Table 5. The metabolic mixture utilized during $6 \mathrm{~h}$ at rest without alcohol, at rest after alcohol, and exercise after alcohol

(Mean values and standard deviations for nine subjects)

$\begin{array}{lccc} & \text { Rest } & \text { Rest with alcohol } & \text { Exercise with alcohol } \\ \text { Protein (g) } & 19 \cdot 8 \pm 2 \cdot 9 & 17 \cdot 4 \pm 2 \cdot 9 & 17 \cdot 0 \pm 3 \cdot 2 \\ \text { Fat (g) } & 33 \cdot 4 \pm 12 \cdot 9 & 11 \cdot 7 \pm 4 \cdot 4 & 66 \cdot 1 \pm 23 \cdot 4 \\ \text { Carbohydrate (g) } & 27 \cdot 4 \pm 25 \cdot 1 & 32 \cdot 9 \pm 12 \cdot 9 & 92 \cdot 3 \pm 75 \cdot 3 \\ \text { Alcohol (g) } & - & 30 \cdot 8 \pm 5 \cdot 7 & 29 \cdot 5 \pm 4 \cdot 5 \\ \text { Calories (kcal) } & 504 \pm 53 & 534 \pm 60 & 1236 \pm 113\end{array}$

Table 6. Mean values for the percentage distribution of the sources of energy in nine subjects at rest, with and without alcohol, and exercising after alcohol

$\begin{array}{lccr} & \text { Rest } & \text { Rest with alcohol } & \text { Exercise with } \\ \text { Protein } & \text { I6 } & \text { 14 } & 6 \\ \text { Fat } & 61 & 20 & 46 \\ \text { Carbohydrate } & 23 & 25 & 31 \\ \text { Alcohol } & - & 41 & 17\end{array}$

Table 5 shows the metabolic mixture utilized over the $6 \mathrm{~h}$ period of each experiment. Table 6 shows the proportion of the calories provided by each of the four fuels. These figures have been calculated from the values obtained by the method of Consolazio, Johnson \& Pecora ( 1963 ). In calculating the alcohol utilized by the tissues it was assumed that $95 \%$ of the alcohol cleared was metabolized. No measurements 
of the alcohol content of the expired air or of the urine were made. An estimate of $5 \%$ for these losses is generous (Lundsgaard, r953).

It will be seen that at rest the alcohol supplied $4 \mathrm{I} \%$ of the calories and this was entirely at the expense of calories from fat; the rate of utilization of carbohydrate and protein was not significantly changed. Unfortunately no control experiment was done with exercise without alcohol.

Table 7 shows the calculation of the complete water balance in the three series of experiments. It will be seen that the urine output was very variable and at rest the alcohol had no constant diuretic action. The evaporative water loss will be seen to be exactly the same with or without alcohol at rest. The evaporative water loss is recognized to be a measure of the metabolic rate (Newburgh, 1950), and the fact that there is no difference between the two figures confirms the lack of difference between the oxygen figures in these states.

\section{Table 7. Complete water balance over $6 \mathrm{~h}$ in nine subjects at rest, with and without alcohol, and exercising after alcohol}

\begin{tabular}{|c|c|c|c|c|}
\hline \multicolumn{5}{|c|}{ (Mean values and standard deviations) } \\
\hline & & Rest & $\begin{array}{c}\text { Rest with } \\
\text { alcohol }\end{array}$ & $\begin{array}{l}\text { Exercise with } \\
\text { alcohol }\end{array}$ \\
\hline In: & $\begin{array}{l}\text { intake }(\mathrm{g}) \\
\text { metabolic }(\mathrm{g})\end{array}$ & $\begin{array}{c}643 \pm 53 \\
61 \pm 5^{\circ} 0\end{array}$ & $\begin{array}{c}707 \pm 58 \\
69 \pm 8 \cdot 6\end{array}$ & $\begin{array}{r}1340 \pm 92 \\
161 \pm 18\end{array}$ \\
\hline Out & $\begin{array}{l}\text { urine (g) } \\
\text { blood }(g) \\
\text { evaporative loss (g) }\end{array}$ & $\begin{array}{c}701 \pm 390 \\
\overline{252 \pm 36}\end{array}$ & $\begin{array}{l}817 \pm 326 \\
21 \pm 3 \cdot 8 \\
251 \pm 48\end{array}$ & $\begin{array}{c}613 \pm I I 4 \\
24 \pm 4 \cdot I \\
\text { I } 51 \pm I 24\end{array}$ \\
\hline Bala & nce $(g)$ & $-263 \pm 371$ & $-362 \pm 318$ & $-301 \pm 29 I$ \\
\hline
\end{tabular}

We have looked carefully at the papers from Sweden and Japan which indicate that alcohol has a specific dynamic action and is utilized by muscle, and we are quite unable to explain the difference between these results and ours. Numerous other workers are in agreement with our findings (for a review see 'Trémolières \& Carré, 1959).

\section{SUMMARY}

I. Alcohol $\left(3{ }^{1} 5 \mathrm{~g} / 65 \mathrm{~kg}\right)$ was given to nine subjects and the metabolic changes followed for $6 \mathrm{~h}$ on two occasions, once with complete rest and once with periods of exercise amounting to an 8-mile walk. No specific dynamic effect of the alcohol was observed and the exercise did not increase the rate of elimination of alcohol. These results are contrary to two recent reports in the literature, but in agreement with classical findings.

2. In experiments at rest, alcohol was shown to spare fat metabolism and the rate of carbohydrate metabolism was unchanged.

We wish to thank the subjects for their cheerful co-operation in this experiment and Mr D. Shirling and Mr C. T. M. Davies for help with the analytical work. 


\section{REFEREN CES}

Consolazio, C. F., Johnson, R. E. \& Pecora, L. J. (1963). Physiological Measurements of Metabolic Functions in Man, p. 314. New York: McGraw Hill.

Lundsgaard, E. (1953). World Health Organization, Report to the Expert Committee on Alcohol. Geneva: World Health Organization.

Nagamine, S., Tezuka, T., Yamakawa, K. \& Suzuki, S. (I96r). Rep. natn. Inst. Nutr., Tokyo, p. 7.

Newburgh, L. H. (1950). In Clinical Nutrition, p. 689. [N. Jolliffe, F. F. Tisdall and P. R. Cannon, editors.] New York: Paul B. Hoeber Inc., Medical Book Department of Harper Brothers.

Perman, E. (1962). Acta physiol. scand. 55, 207.

'Trémolières, J. \& Carré, L. (1959). Revue de l'Alcoolisme. Vol. 5, no. 3. 